\title{
A SUSTAINABLE REQUALIFICATION OF BRACCIANO LAKE WATERFRONT IN TREVIGNANO ROMANO
}

\author{
D. ASTIASO GARCIA ${ }^{1}$, F. CUMO ${ }^{2}$, E. PENNACCHIA ${ }^{1} \&$ V. SFORZINI ${ }^{1}$ \\ ${ }^{1}$ DIAEE, Department of Astronautic, Energetic and Electric engineering, Sapienza University of Rome, Italy. \\ ${ }^{2}$ CITERA, Interdepartmental Centre for Territory, Building, Conservation and Environment, \\ Sapienza University of Rome, Italy.
}

\begin{abstract}
This paper describes the first interventions carried out in accordance with the results of the three years bilateral research SoURCE (Sustainable Urban Cell) performed by CITERA (Inter department Centre for Territory, Building, Conservation and Environment) of the Sapienza University of Rome and the Department of Urban Planning and Environment of the Royal Institute of Technology of Stockholm (KTH) regarding urban redevelopment and distributed micro-generation of buildings. The location is the municipality of Trevignano Romano in the area (urban cell) of the lake waterfront aimed at the integration of all facilities that will increase the tourist accommodation of the area. The concept of the project is to utilize empty spaces, in all lake waterfronts, for the construction of public toilets and showers, introduction of electric boat and bike rental for sightseeing with charging stations and construction of an energy efficient wooden prefabricated building to be used as a general shop for tourists (closest analogue service is about $3 \mathrm{~km}$ ). The research is included in the executive programme for the scientific and technical cooperation between the Kingdom of Sweden and the Republic of Italy, in the area defined 'Energy and Environment: Sustainable Cities'.

Keywords: Eco-compatible materials, renewable energies, sustainable mobility, sustainable tourist accommodation.
\end{abstract}

\section{INTRODUCTION}

The first Italian case study of the SoURCE project was Trevignano Romano, due to stringent environmental requirements for the built environment. It was chosen because the entire municipal area falls within the Regional Natural Park of Bracciano-Martignano that has a high environmental value for the conservation of local biodiversity. The municipality area has been divided into four 'urban cells' (Fig. 1) that are elementary units of territory in order to optimize the use of renewable energy together with and overall energy efficiency of the existing buildings and structures (Table 1).

An energy balance was performed in order to show the potential of energy improvement of each urban cell.

Trevignano is located on the northern shore of Bracciano Lake, on the slopes of a cliff, next to the characteristic Gulf of Cucumino; the basin has a volcanic origin, as the entire orographic apparatus of Sabatini mountains. The altitude of the lake in normal condition is $164 \mathrm{~m}$ above sea level, and the medium altitude of the city is $173 \mathrm{~m}$ above sea level. The surface of the municipality reaches an area of $39.4 \mathrm{~km}^{2}$ almost entirely subject to landscape protections. The resident population is about 6000 inhabitants. The climate is temperate and according to the Italian classification, the municipality is in 'D' climate area. The City of Trevignano adopted in 2003, a variant of the PRG (the urbanistic general plan) in accordance with the Regional Law No. 29/1997 and the Regional Law No. 36/1999, which established the Parco Naturale Regionale del complesso lacuale di Bracciano-Martignano, and according to the Landscape Plan, in recent years, the district has seen the development - although with a lesser extent than other municipalities - of residential settlements, which are especially made up of second homes. These expansions had affected several parts of territory without following any planning and, in many cases, they are characterized by a low quality level and a high environmental 
impact, with a significant alteration of the natural original landscape, also visible from the opposite side of the lake.

Despite this, the environmental situation is still not compromised compared to other settlements in the surrounding area. The landscape and climate quality, the beauty of the city center, and the supply of recreational and cultural initiatives, make Trevignano a popular tourist resort. The road infrastructure was originally formed by the Settevene-Palo road and the access routes to the Cassia. After the completion of the ring Circumlacuale, during the 1950s, roads have remained unchanged and are now inadequate for the flow of traffic making them very intense in the summer season and over the weekends.

\section{ENERGY BALANCE OF URBAN CELLS AND INTERVENTIONS OF URBAN REDEVELOPMENT}

The urban area of Trevignano Romano is not very extensive and therefore the energy analysis was performed by in situ and satellite surveys, considering both the data of energy bills and the outputs of the energy simulators.

To be more specific, according to a previous elaborated methodology [1], for each building a database made-up by the following information was realized: age of construction, types of building construction, types of casings, HVAC (cooling and heating systems), and building typologies (residential, commercial, or public).

This information was used to estimate the energy consumptions of each building. Figures 2 and 3 reported the spatial representation of energy outputs in the waterfront urban cell.

In order to summarize the obtained results, Table 2 reported the expenditure of energy of each urban cell.

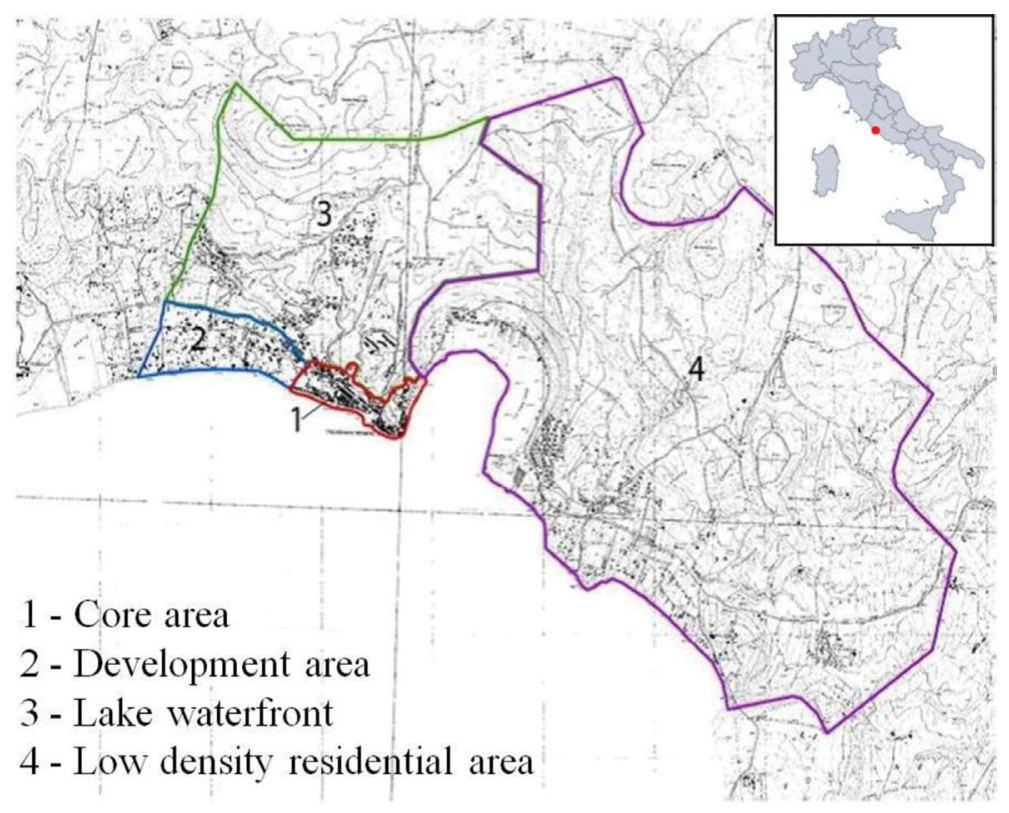

Figure 1: Trevignano Romano urban cells. 
Table 1: Trevignano Romano urban cells data.

\begin{tabular}{ll}
\hline Core area & \\
\hline Area & 36.6 ha of which: 10.39 ha arboreal; 1.2 ha forestry; 21.01 ha urban \\
& area \\
Population & 2000 \\
Overall buildings & 13.95 ha (409 buildings) \\
Housing units & $89.30 \%$ (1549 housing units) \\
Public buildings & $7.10 \%$ \\
Commercial activities & $5.60 \%$ (237 main shops) \\
Development area & \\
Area & 1.070 ha of which: 637.56 ha agricultural; 225 ha forestry; 207.44 ha \\
& urban area \\
Population & 1000 \\
Overall buildings & 8.5 ha (564 buildings) \\
Housing units & $98.00 \%$ (713 housing units) \\
Public buildings & $0.00 \%$ \\
Commercial activities & $2.00 \%$ (25 main farm shops) \\
Lake waterfront & \\
Area & 89 ha of which: 65.17 ha agricultural; 1.33 ha forestry; 22.5 ha urban \\
& area \\
Population & 1500 \\
Overall buildings & 4.82 ha (265 buildings) \\
Housing units & $97.00 \%$ (474 housing units) \\
Public buildings & $0.50 \%$ \\
Commercial activities & $2.50 \%$ (25 main restaurants) \\
Low density residential area & 472 ha of which: 223.38 ha agricultural; 159.03 ha forestry; 89.59 ha \\
Area & urban area \\
Population & 1500 \\
Overall buildings & 11.78 ha (391 buildings) \\
Housing units & $98.00 \%$ (768 housing units) \\
Public buildings & $1.50 \%$ \\
Commercial activities & $0.50 \%$ (6 main shops) \\
\hline &
\end{tabular}

The trend of thermal consumption is mainly influenced by the number of buildings and their energy performance while the electric consumption is connected to both the number of housing units with electric cooling systems as well as mainly the commercial activities in the urban area.

Due to the lack of strong and constant wind, in order to estimate the potential of renewable energy for improving local air quality and reducing greenhouse gas emissions [2], it was hypothesized to install only photovoltaic systems (PV arrays) with an electric power of $3 \mathrm{~kW}$ of the cell, and solar 


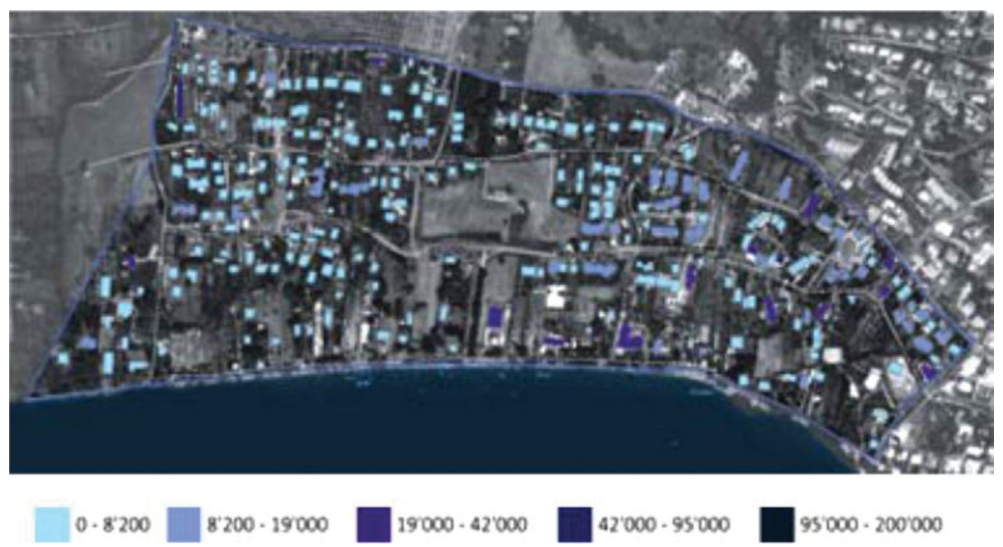

Figure 2: Electric consumption estimated in kWht/year of Bracciano Lake waterfront.

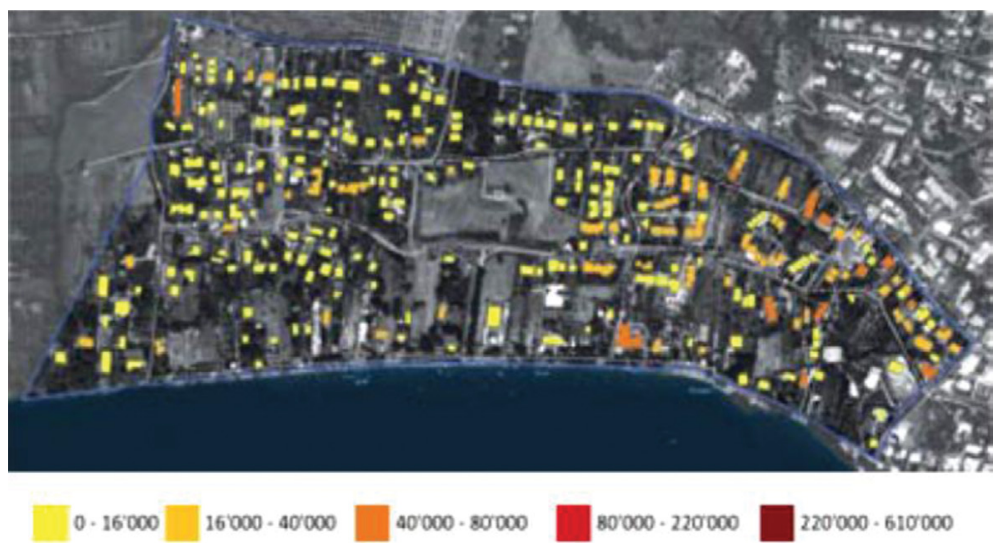

Figure 3: Thermal consumption estimated in kWht/year of Bracciano Lake waterfront.

thermal (ST) systems with a plan surface of $4 \mathrm{~m}^{2}$ on the residual useful roof $\left(14.220 \mathrm{~m}^{2}\right.$ for PV and $6.236 \mathrm{~m}^{2}$ for ST respectively).

The reduction of consumption was evaluated hypothesizing the replacement of the casing of windows, energy retrofit of HVAC (thermostatic valve and high efficiency hot-water heater) and the use of electric appliances with higher performance.

It is possible to observe in these cells that there are less housing units than other cells and there are few commercial activities, following the energy consumption is less than the others.

The energy balance shows that it is possible to reduce the thermal and electric consumptions by the contributions of renewable energies and actions of retrofit; in specific, the renewable resources compensate about $30 \%$ of actual consumption. At the same time, the retrofit actions of HVAC and building structure on the entire territory guarantee a reduction of $25 \%$ of the actual consumption.

The final balance is obtained by a comparison between the actual consumption and specific combination of renewable energies and retrofit actions (Figs 4 and 5). 
Table 2: Energy balance of each Trevignano Romano urban cells (Cell 2: lake waterfront).

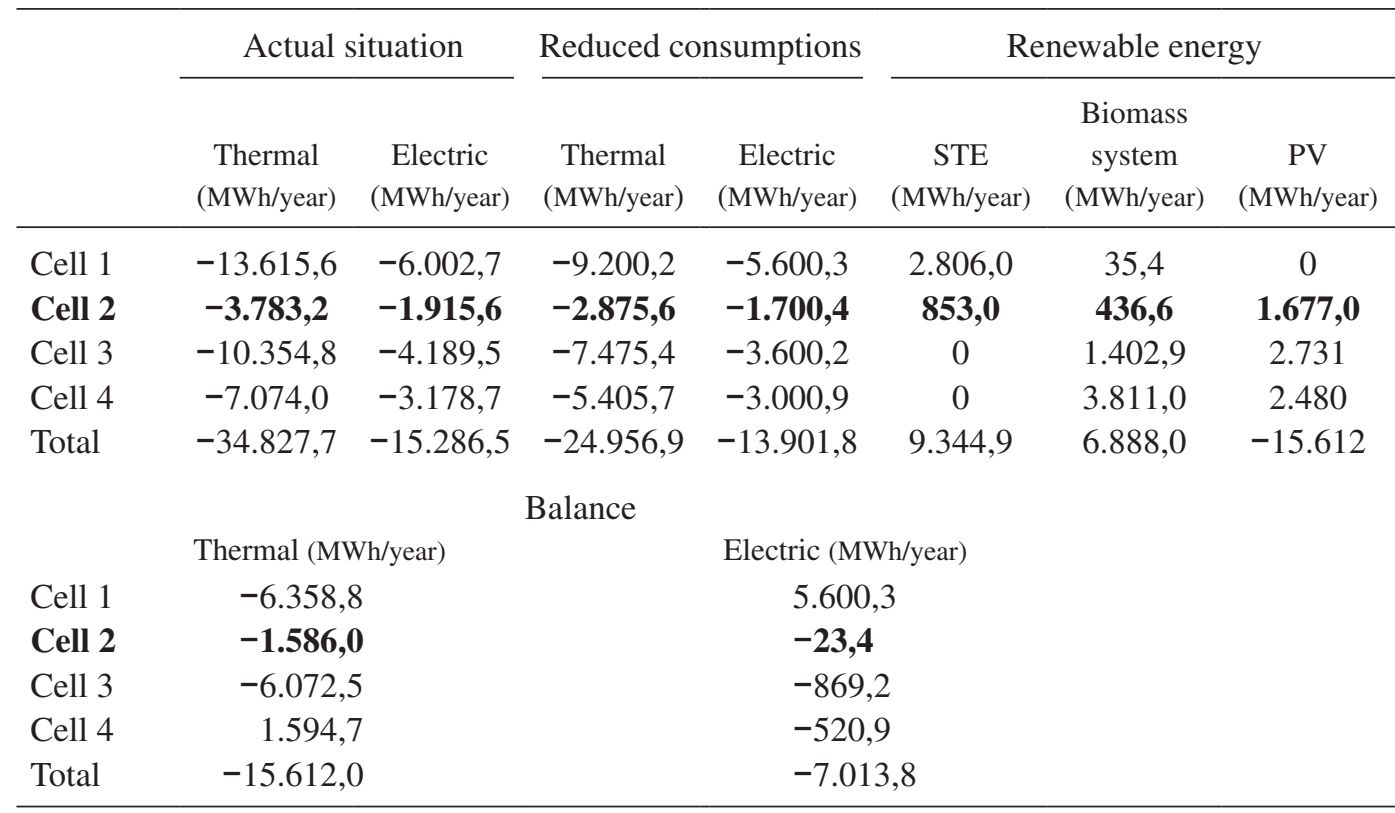

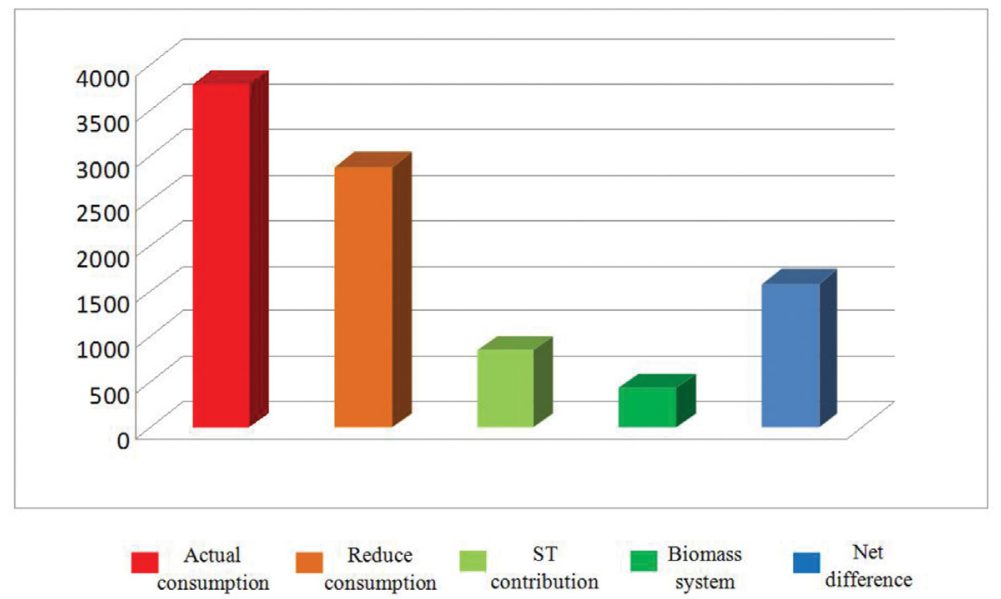

Figure 4: Urban cells thermal balance (MWh/year).

The negative values of the balance of all cells underline that it is not possible to obtain zero consumption, only reduce them.

\section{ENERGY REQUALIFICATION INTERVENTIONS ALONG LAKE WATERFRONT}

The Energy requalification intervention of the bathers services in Rena road foresees the construction of a kiosk for the electric bikes rental (Fig. 6). It is equipped with the photovoltaic roof for 


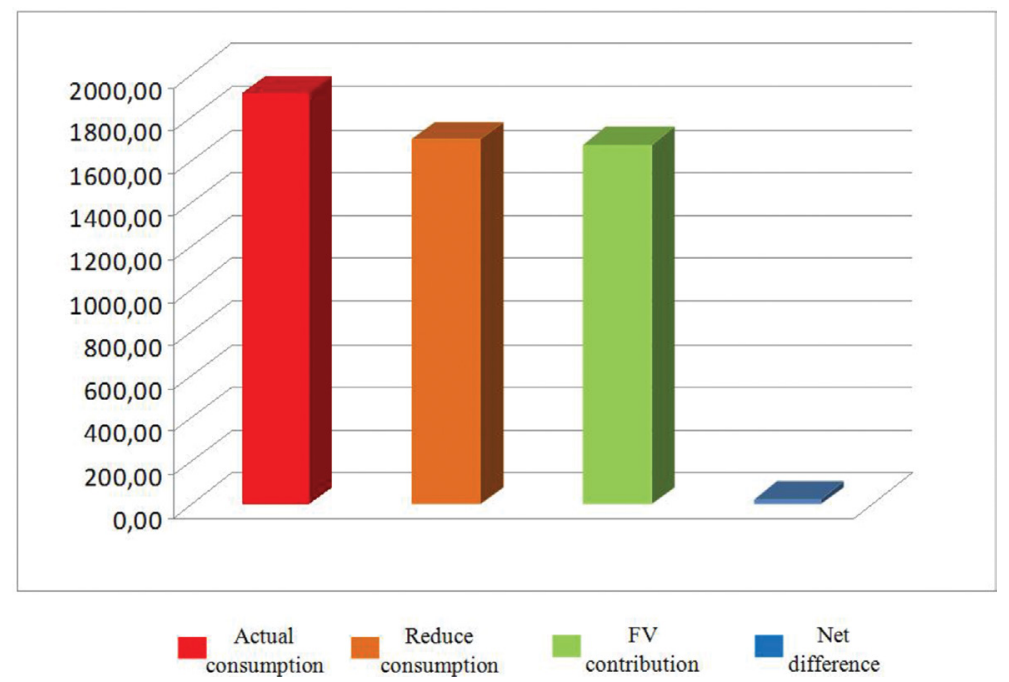

Figure 5: Urban cells electric balance (MWh/year).

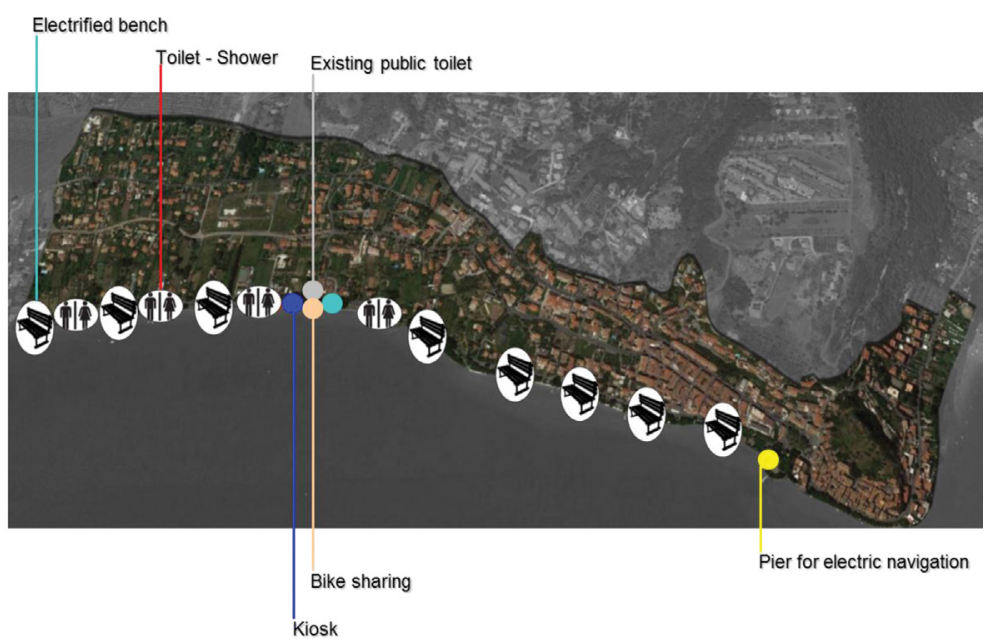

Figure 6: Localization of the energy requalification interventions along the lake waterfront.

electric bike charging, public toilets, and hot showers close to the beach supplied by ST collectors. Moreover, the project foresees a structure for electric boats rental, each equipped with PV arrays for batteries recharging.

The sustainable mobility interventions involve the installation of charging stations for electric vehicles in various areas that will be realized according to the criteria of bio-architecture for natural protected areas elaborated by the Sapienza University of Rome in collaboration with the General Directorate for the Protection of Nature of the Italian Ministry for the Environment [3-7]. 
The project will be realized by pursuing the best possible integration of structures and appropriate technologies to maximize energy efficiency and design quality for environmental impacts mitigation in areas of high environmental value.

Moreover, it is planned to optimize the usability of the tourism network through the implementation of facilities for eateries or tourism information point, or centers for the dissemination of information on the surrounding ecosystems, in order to increase visitors' awareness on the principles of environmental conservation and sustainability.

\subsection{Rental service and recharge of electric bike system}

A light structure will be built using eco-friendly materials - locally and naturally perishable as the chestnut wood - to be installed without any ground handling operation in compliance with the Protected Area legislation. The project design foresees simple modular constructions mainly based on the prefabrication principles. The structure will be located in a service area adjacent to an existing structure used as a public bath and will host a selling point on an open space.

In particular, the building materials are all natural and perfectly integrated with the colors and characteristics of the surrounding landscape. The kiosk will occupy a floor area of $9 \mathrm{~m}^{2}$ with an average height of $3 \mathrm{~m}$. The construction will be done by assembling modular components of wood-in particular composed of laminated wood beams of chestnut and oriented strand board (OSB) panels-of athickness of $26 \mathrm{~mm}$.

The structure is temporary and completely removable, thanks to the lack of foundation on the ground; the kiosk will be set on a platform filled with stones for anchoring to the ground the entire construction in the event of exposure to strong winds or other sudden strains. Moreover, the building covering will have a maximum slope of $10 \%$, to allow rain water runoff (Fig. 7).

Furthermore, an outdoor lighting system will be installed along the external perimeter, in order to allow the use of the area in the evening.

Considering that energy sustainability in an adjacent area will be realized, a photovoltaic shelter can be built as a charging station for two electric cycles or scooters (Fig. 8). The 10-kW PV system is totally self-sufficient but it can also be connected to the existing electricity grid.

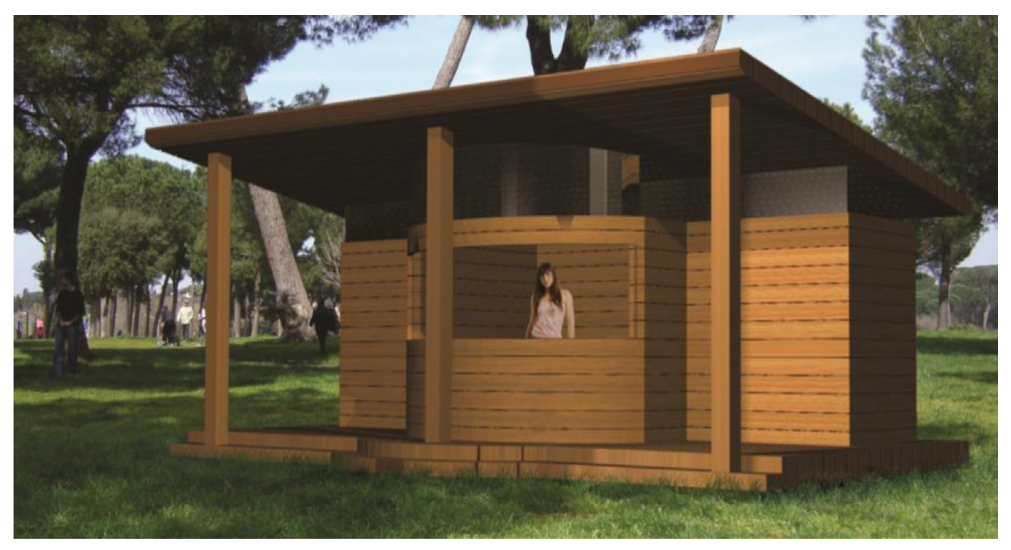

Figure 7: Sustainable kiosk design. 


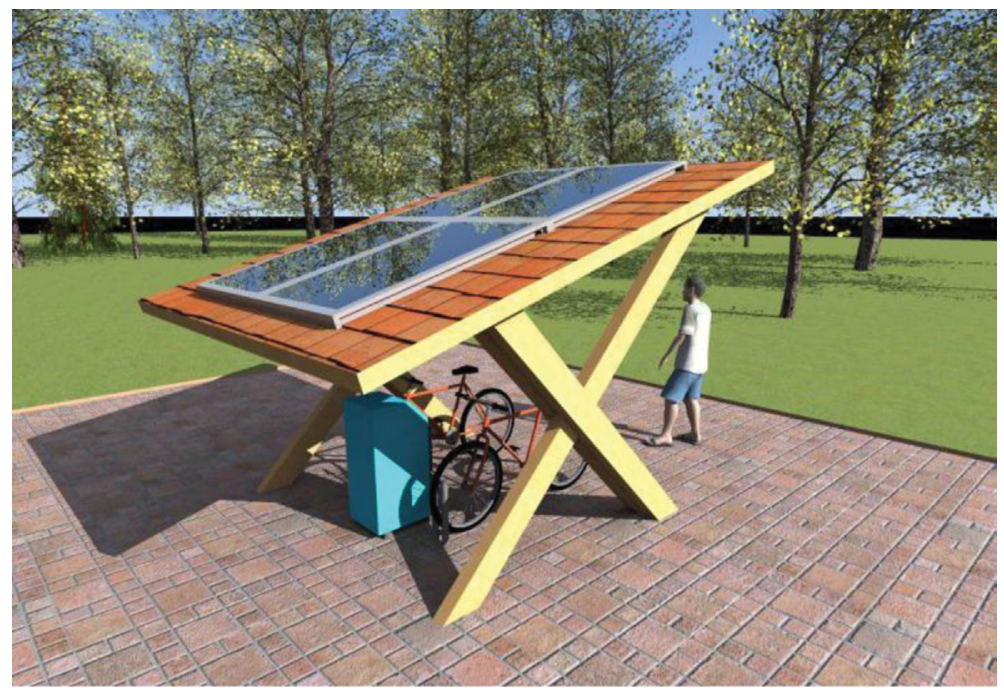

Figure 8: Photovoltaic shelter for electric cycles.

\subsection{Service building and facilities for electric navigation and bathers}

The project foresees the realization of an eco-friendly kiosk designed under the principles of prefabrication and removability; considering its energy performances, it is autonomous due to the presence of photovoltaic panels integrated with its roof-thermal solar collectors for the production of hot sanitary water and a rainwater recovery system (Fig. 9).

The kiosk occupies a surface area of about $60 \mathrm{~m}^{2}$ and is on an average $3 \mathrm{~m}$ high. On the northern side there are sanitary services and a storage and a technical room where the batteries of the photovoltaic plant are housed and the batteries of the electrically powered touristic boat are recharged. A bar and a ticket office are situated on the southern side (Fig. 10). Moreover, there is a small pier for a mini-cruise service, for the promotion of sustainable tourism in the lake area. In fact, according to the local legislation, only electrically powered navigation is allowed in Lake Bracciano . The mini-cruise service will be realized using a coast guard boat that is no longer in use, carrying 20 people at the most, that will be equipped with an electrical engine supplied by the PV arrays of the roof of the building.

\section{CONCLUSIONS}

The above mentioned results, including energy balance of urban cells, interventions of urban redevelopment and energy requalification interventions for sustainable tourism along the Bracciano lake waterfront, have been presented to the local administrations as ad hoc strategies for the planning of energy management in their territories. In fact, each one of the described energy efficiency solutions has been designed considering any peculiar social, economic, natural, and cultural context of the area. This approach was successfully realized with Trevignano Romano Municipalities during and after the elaboration of the case study, providing decision-makers and local assessors with the elaborated GIS database of their jurisdiction area. These applications highlighted that tourism sustainability is not a matter of rules or solutions that are effective in any circumstance, but the real challenge is to find the best solution for any peculiar social, economic, natural, and cultural context in which an intervention is required. 


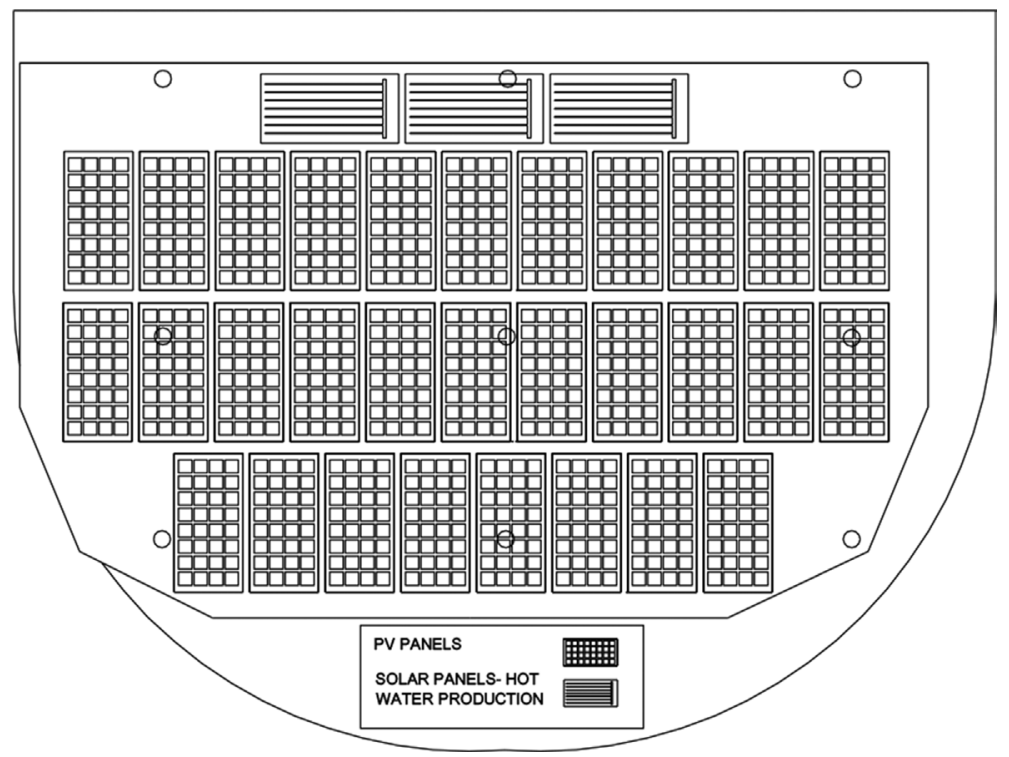

Figure 9: PV arrays and solar panels distribution in the roof of the eco-friendly kiosk.

FLOOR PLAN

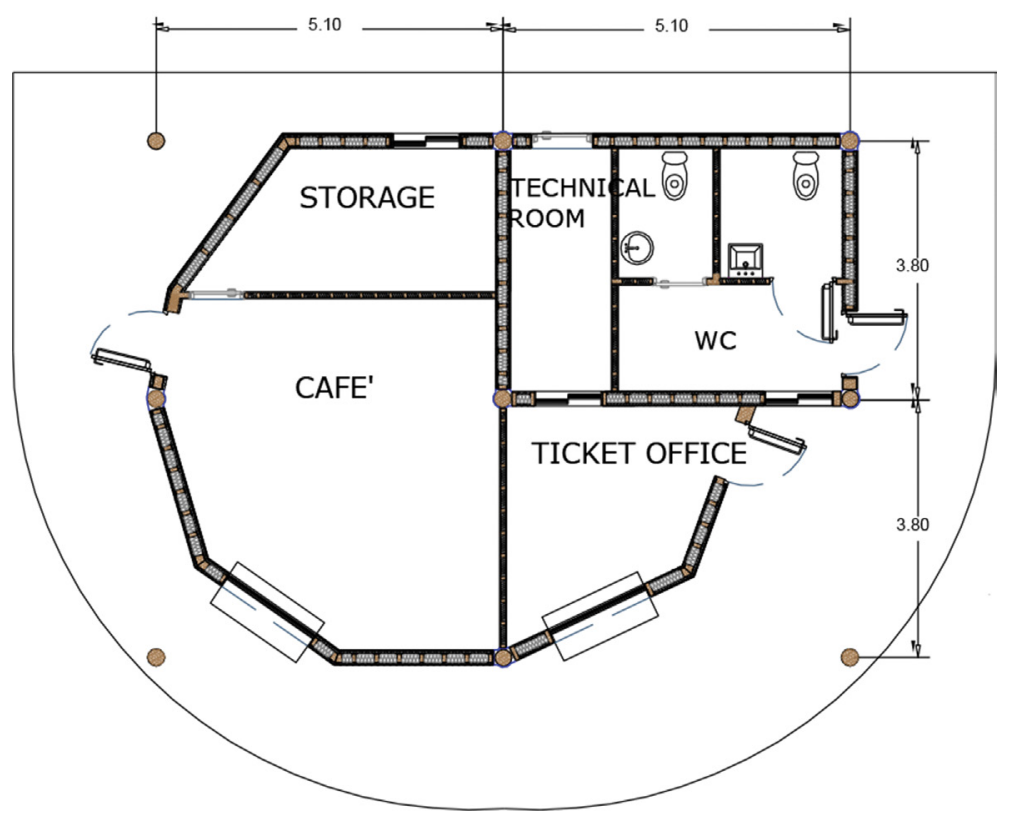

Figure 10: Spatial distribution of the services in the eco-friendly kiosk. 
A starting point for future developments for the implementation of a smart grid, each renewable energy source described earlier can be interconnected within smart grids in order to achieve a larger primary energy saving and a carbon reduction as well [8]. Moreover, clean energy storage systems could be considered. Among these, the renewable hydrogen represents a viable clean storage solution which offers several applications such as hydrogen enriched natural gas blends $\left(\mathrm{H}_{2} \mathrm{NG}\right)$ and the deferred load meeting by fuel cell integration [9-11].

\section{REFERENCES}

[1] Cumo, F., Astiaso Garcia, D., Calcagnini, L., Rosa, F. \& Sferra, A.S., Urban policies and sustainable energy management. Sustainable Cities and Society, 4, pp. 29-34, 2012. doi: http:// dx.doi.org/10.1016/j.scs.2012.03.003

[2] Astiaso Garcia, D., Cinquepalmi, F. \& Cumo, F., Air quality in Italian small harbours: a proposed assessment methodology. Rendiconti Lincei, Springer: Milan, 24(4), pp. 309-318, 2013. doi: http://dx.doi.org/10.1007/s12210-013-0254-0

[3] Astiaso Garcia, D., Cumo, F. \& Sforzini V., Eco friendly service buildings for sustainable tourism and environmental awareness in protected areas. WIT Transactions on Ecology and the Environment, 161, pp. 323-330, 2012. doi: http://dx.doi.org/10.2495/st120261

[4] Astiaso Garcia, D., Bruschi, D., Cinquepalmi, F. \& Cumo, F., An estimation of urban fragmentation of natural habitats: case studies of the 24 Italian national parks. Chemical Engineering Transaction, ICheaP-11,1 $11^{\text {th }}$ International Conference on Chemical \& Process Engineering, 32, pp. 49-54, 2013.

[5] Cinquepalmi, F., Cumo, F., Gugliermetti, F. \& Sforzini, V., Advanced technologies for sustainable building in the protected areas: two case studies in Italy. WIT Transactions on Ecology and the Environment, 128, pp. 551-560, 2010. doi: http://dx.doi.org/10.2495/arc100471

[6] De Santoli, L., Astiaso Garcia, D. \& Violante, A.C., Planning of flood defence management and rehabilitation of the natural habitat in the downstream part of the river Tiber. WIT Transaction on the Built Environment, 100, pp. 25-34, 2008. doi: http://dx.doi.org/10.2495/geo080031

[7] Cumo, F., Cinquepalmi, F., Pennacchia, E. \& Sforzini, V., High performing building as a pier for sustainable tourism in the protected area of Bracciano lake in Italy. WIT Transactions on Ecology and the Environment, 165, pp. 175-182, 2012. doi: http://dx.doi.org/10.2495/arc120161

[8] Motevasel, M. \& Seifi, A.R., Expert energy management of a micro-grid considering wind energy uncertainty. Energy Conversion and Management, 83, pp. 58-72, 2014. doi: http://dx.doi. org/10.1016/j.enconman.2014.03.022

[9] De Santoli, L., Lo Basso, G. \& Bruschi, D., Hybrid system with an integrated CHP plant fuelled by $\mathrm{H}_{2} \mathrm{NG}$ blends: theoretical energy-environmental analysis and foreseeable optimizations. Energy and Building, 71, pp. 88-94, 2014. doi: http://dx.doi.org/10.1016/j.enbuild.2013.12.008

[10] De Santoli, L., Lo Basso, G. \& Bruschi, D., Energy characterization of CHP (combined heat and power) fuelled with hydrogen enriched natural gas blends. Energy, 60, pp. 13-22, 2013. doi: http://dx.doi.org/10.1016/j.energy.2013.07.012

[11] De Santoli, L., Lo Basso, G. \& Bruschi, D., A small scale $\mathrm{H}_{2} \mathrm{NG}$ production plant in Italy: techno-economic feasibility analysis and costs associated with carbon avoidance. International Journal of Hydrogen Energy, 39(12), pp. 6497-6517, 2014. doi: http://dx.doi.org/10.1016/j. ijhydene.2014.02.003 